\title{
PENGARUH DISIPLIN KERJA TERHADAP KINERJA PERAWAT DI RUMAH SAKIT DUSTIRA CIMAHI, JAWA BARAT
}

\section{Sari Hijayanti}

Akademi Fisioterapi RS. Dustira Cimahi

Email: sari.fishijayanti@gmail.com

\begin{tabular}{|c|c|}
\hline INFO ARTIKEL & ABSTRAK \\
\hline $\begin{array}{l}\text { Tanggal diterima: } 5 \text { Oktober } \\
2020 \\
\text { Tanggal revisi: } 10 \text { Oktober } \\
2020 \\
\text { Tanggal yang diterima: } 25 \\
\text { Oktober 2020 } \\
\text { Kata kunci: } \\
\text { Disiplin kerja; komunikasi } \\
\text { interpersonal; kinerja. }\end{array}$ & $\begin{array}{l}\text { Penelitian ini bertujuan untuk memperoleh informasi } \\
\text { mengenai keterkaitan antara disiplin kerja dan komunikasi } \\
\text { interpersonal terhadap kinerja pegawai rehabilitasi medik Di } \\
\text { Rumah Sakit Dustira Cimahi Jawa Barat, baik secara sendiri- } \\
\text { sendiri maupun secara bersama-sama. Penelitian ini } \\
\text { menggunakan metode penelitian survey yang dirancang } \\
\text { untuk memperoleh informasi tentang pengaruh disiplin kerja } \\
\text { dan komunikasi interpersonal terhadap kinerja pegawai } \\
\text { rehabilitasi medik Di Rumah Sakit Dustira Cimahi Jawa } \\
\text { Barat, baik secara sendiri-sendiri maupun secara bersama- } \\
\text { sama. Didapatkan hasil penelitian yang pertama yaitu } \\
\text { terdapat pengaruh positif disiplin terhadap kinerja pegawai } \\
\text { rehabilitasi medik Di Rumah Sakit Dustira Cimahi Jawa } \\
\text { Barat, yang kedua terdapat pengaruh positif komunikasi } \\
\text { interpersonal terhadap kinerja pegawai rehabilitasi medik Di } \\
\text { Rumah Sakit Dustira Cimahi Jawa Barat dan yang ketiga } \\
\text { yaitu terdapat pengaruh positif disiplin kerja dan komunikasi } \\
\text { interpersonal secara bersama-sama terhadap kinerja kinerja } \\
\text { pegawai rehabilitasi medik Di Rumah Sakit Dustira Cimahi } \\
\text { Jawa Barat. }\end{array}$ \\
\hline
\end{tabular}

\section{Pendahuluan}

Program pembangunan Nasional direncanakan untuk meningkatkan mutu kehidupan masyarakat dengan menciptakan individu-individu manusia Indonesia seutuhnya yang dapat mengembangkan potensinya secara optimal. berkesinambungan merupakan upaya peningkatan Sumber Daya Alam (SDA) yang dilakukan secara dini dalam satu siklus kehidupan manusia yang selanjutnya disebut sebagai Sumber Daya Manusia (SDM) dini.

Reformasi merupakan titik tonggak perubahan paradigma kepemerintahan di Indonesia, adanya tuntutan perubahan dalam kinerja aparat pemerintah menjadi pekerjaan rumah yang sangat berat bagi pemerintah, betapa tidak kondisi yang telah berjalan bertahun-tahun harus dirubah total. Tuntutan tersebut adanya perubahan kinerja pegawai pada proses pelaksanaan tugas (Hermawati, 2017). Sumber Daya Manusia (SDM) merupakan faktor utama dan strategis bagi tercapainya keberhasilan pembangunan suatu bangsa. SDM yang kuat dan berdaya saing tinggi dalam berbagai aspek akan mendukung peningkatan pembangunan, baik di bidang ekonomi, kesehatan maupun di bidang sosial dan budaya. SDM yang berdaya saing tinggi merupakan salah satu faktor kunci keberhasilan di era globalisasi yang diwarnai dengan semakin ketatnya persaingan serta 
tiadanya batas antar negara dalam interaksi hidup dan kehidupan manusia. Oleh karena itu, untuk memenangkan dan menangkap peluang yang ada, pengembangan SDM harus ditekankan pada penguasaan kompetensi yang fokus pada suatu bidang tertentu yang pada gilirannya akan mampu meningkatkan bidangbidang tertentu untuk pembanguanan Negara (Irwansyah, Adhinugraha, \& Wijaya, 2011) .

Pembangunan Sumber Daya Manusia yang berkualitas dimasa depan bertujuan untuk mencetak manusia yang menguasai ilmu dan teknologi serta mencetak manusia yang beriman dan bertakwa (iptek dan imtak). Di samping dikaitkan dengan kemampuan sumber daya manusia, produktivitas juga kerap dikaitkan dengan cara dan sistem yang efisien (Afriandi, 2017). Sumber daya manusia yang berkualitas akan dapat tercermin dari pola pikir, kesadaran, kemauan, semangat dan etos kerja yang tinggi. Untuk mewujutkan sumber daya manusia yang beriptek dan berimtak akan dipengaruhi oleh berbagai faktor antara lain tingkat pendidikan, pengalaman kerja, semangat kerja, kiat dari indifidu untuk mau berubah menuju yang lebih baik, manajemen yang diterapkan, pengawasan dan pembinaan yang dilakukan (Irwansyah et al., 2011).

Rumah sakit merupakan institusi yang bergerak dalam bidang penjual jasa pelayanan publik dalam bidang kesehatan, untuk itu segala aktifitas yang dilakukan merupakan suatu sistem yang saling terkait dan sama memiliki tingkat kepentingan yang sama (Pusparini, 2008). Untuk mendukung tercapainya kualitas pelayanan publik di rumah sakit yang berkualitas perlu di dukung sumber daya manusia yang berkualitas pula.

(Rochmanadji, 2009) dalam "Being $a$ Great and Sustainable Hospital" menyatakan rumah sakit merupakan organisasi pelayanan kesehatan yang unik dan serba padat, yaitu padat usaha, padat modal, padat kemuktahiran ilmu teknologi, padat sumber daya manusia (SDM) dan profesi karena berhadapan dengan dampak internal multiusaha rumah sakit, yaitu padat masalah. Fenomena rumah sakit sebagai padat masalah tersebut diperburuk oleh munculnya masalah regional dan global, yakni perubahan yang terjadi dengan sangat cepat, tantangan persaingan bebas, tuntutan perencanaan strategis berbasis kinerja, serta lahirnya paradigma organisasi dan kepemimpinan masa depan. Tantangan lingkungan lainnya yang dihadapi oleh rumah sakit adalah masyarakat yang kini cenderung SDM yang berkualitas akan memberikan kontribusi yang positif terhadap peningkatan produktivitas dan pertumbuhan ekonomi sehingga dapat mengurangi angka kemiskinan. Segala macam aspek yang berkaitan dengan sumberdaya manusia pada akhirnya turut mempengaruhi output perusahaan yang bersangkutan. Mengingat perannya yang sangat penting, maka sudah selayaknya suatu perusahaan melakukan suatu mekanisme pemeliharaan sumberdaya manusia dengan memperhatikan kinerja karyawan-karyawannya (Utomo \& Nuraeni, 2019). Pegawai rekam medik yang memiliki kinerja yang baik akan mendapat perhatian yang serius dari pihak atasan, dan atasan akan memperhatikan pula segala tuntutannya sehingga pegawai rekam medik tersebut dapat dikatakan memiliki kemampuan untuk memenuhi kebutuhan hidupnya baik untuk kerja maupun untuk hidup bermasyarakat. Pegawai yang demikian memiliki mutu kehidupan kerja yang baik karena mampu menciptakan kondisi kerja yang mendukung adanya komunikasi yang baik antara dirinya sebagai pegawai dan atasan sebagai pimpinannya. 
Setiap pegawai memiliki tingkat kinerja yang berbeda-beda. Hal ini disebabkan karena setiap individu memiliki kemampuan yang berbeda dalam hal menangkap suatu pengetahuan dan keterampilan. Hasil penelitian yang dilakukan (Sutanto \& Suwondo, 2015) menyebutkan bahwa pembinaan hubungan antar karyawan dengan karyawan lain dan atasan dapat menciptakan lingkungan kerja yang baik, yang nantinya akan dapat berpengaruh terhadap kinerja karyawan di perusahaan Selain sifat dari setiap individu itu sendiri juga banyak berpengaruh terhadap kemampuan pegawai. Hal ini disebabkan oleh adanya perbedaan dalam tingkat kemampuan dan sifat individual (M. Yani, 2014).

Disiplin kerja merupakan bagian atau variabel yang sangat penting dalam pengembangan sumber daya manusia. Oleh karena itu, disiplin kerja diperlukan dalam suatu organisasi agar tidak terjadi keteledoran, penyimpangan atau kelalaian yang menyebabkan terjadinya pemborosan dalam melakukan pekerjaan (Nurcahyo, 2011). Lingkungan kerja yang nyaman dapat menjamin karyawan bersemangat dalam bekerja (Djalali, 2016). Oleh karena itu pihak manajemen melakukan berbagai upaya untuk menunjang terciptanya kinerja yang tinggi pada diri pegawainya. Manajemen organisasi memerlukan pula pegawai yang berkualitas agar kinerja organisasi dapat berjalan sesuai dengan rencana organisasi. Dengan kata lain, kualitas manajemen yang baik akan mendukung terhadap suasana kerja yang positif dan suasana kerja yang kondusif akan mendukung terciptanya kinerja yang tinggi pula pada diri pegawai.

Keinginan untuk berhasil dalam bekerja dipengaruhi oleh beberapa faktor, dimana faktor-faktor yang mempengaruhi keberhasilan kerja digolongkan menjadi dua yaitu faktor intern dan faktor ekstern diri seseorang. Faktor-faktor tersebut antara lain adalah motivasi, kompensasi, insentif, motivasi dalam diri pegawai didasarkan atas kebutuhan-kebutuhan, diantara kebutuhan tersebut adalah jaminan keamanan dan keselamatan kerja, haknya sebagai individu terlindungi, pekerjaan yang menarik perhatiannya, imbalan jasa sesuai dengan kewajiban yang dipertanggungjawabkan, pimpinan yang cakap dan adil, bekerja dalam suatu lingkungan fisik dan sosial yang menyenangkan untuk berprestasi, serta kesempatan untuk memperoleh kemajuan bagi diri dan kariernya (Siswadi, 2014). Pendapat lain menyatakan bahwa kinerja karyawan adalah hasil pekerjaan yang dicapai oleh seseorang berdasarkan persyaratanpersyaratan pekerjaan (Putra, Hasanuddin, \& Wirastuti, 2018).

Salah satu upaya organisasi dalam meningkatkan kinerja pegawai adalah dengan memperhatikan semua kebutuhan pegawai dan menyediakan semua fasilitas yang diperlukan pegawai baik dalam pelaksanaan tugas maupun di luar pelaksanaan tugas (Taurisa, Djastuti, \& Ratnawati, 2012). Selain itu agar dapat mengoptimalkan sumber daya manusia suatu perusahaan dapat juga dilakukan dengan cara meningkatkan kepuasan kerja karyawan yang pada dasarnya merupakan prilaku publik untuk pekerjaan seorang sebagai diferensiasi antara banyaknya ganjaran yang didapatkan pekerja dengan ganjaran yang dipercayai semestinya diterima (Attamimi, 2020). Organisasi sangat menyadari pentingnya perhatian terhadap kesejahteraan seluruh pegawai yang dituangkan dalam bentuk pemberian kesejahteraan yang sifatnya ekonomis, fasilitatif maupun pelayanan. 
Organisasi meyakini bahwa dengan pemberian kesejahteraan kepada pegawai maka semangat dan kegairahan pegawai dalam bekerja akan meningkat. Pegawai akan merasa dihargai dan diperhatikan dengan adanya pemberian kesejahteraan oleh organisasi sehingga kondisi fisik dan mental pegawai beserta seluruh potensi yang dimilikinya akan terpelihara dengan baik. Dengan kondisi fisik dan mental yang baik maka pelayanan rekam medik akan semakin tinggi dan tujuan organisasi akan tercapai.

Sebaliknya, tanpa upaya dari organisasi untuk memperhatikan dan memelihara kondisi fisik dan mental pegawai melalui pemberian kesejahteraan, maka pegawai akan cenderung merasa kurang diperhatikan dan hanya sebagai alat lembaga semata-mata untuk mencapai tujuan organisasi. Jika pegawai sudah merasa kurang mendapat perhatian dari kantor, maka pegawai akan malas untuk bekerja dan kegairahan kerjanya menurun. Lebih jauh lagi, jika pada tahap klimaks pegawai merasa hanya sebagai alat pencapaian tujuan semata tanpa perhatian dan penghargaan dari lembaga, maka akan timbul bermacam-macam aksi protes pegawai .

Pemberian kesejahteraan kepada seluruh pegawai memang memerlukan biaya yang besar. Kendala inilah yang umumnya dirasakan oleh banyak organisasi. Akan tetapi dibandingkan dengan apa yang akan diperoleh organisasi dengan pemberian kesejahteraan pegawai dapat meningkatkan motivasi kerja mereka, maka sudah sewajarnya organisasi memberikan kesejahteraan kepada seluruh pegawai. Selain itu, pemberian kesejahteraan kepada pegawai juga merupakan tanggung jawab organisasi dalam memelihara sumber daya manusia yang dimilikinya.

Disiplin kerja juga memiliki kaitan dengan kinerja pegawai. Pegawai yang memiliki disiplin kerja yang tinggi berarti pegawai tersebut memiliki komitmen terhadap profesinya yang dapat berakibat pada pengurangan berbagai tindak ketidakdisiplinan seperti tidak hadir dan datang terlambat. Jadi dengan adanya komitmen pegawai akan mampu meningkatkan efektivitas organisasi.

\section{Metode Penelitian}

Metode penelitian yang digunakan adalah Survai, Ary, Yacobs and Razavich (1999:382) menyatakan bahwa metode survai dirancang untuk memperoleh informasi tentang status gejala pada saat penelitian dilakukan dengan tujuan untuk melukiskan variabel atau kondisi atau kondisi apa yang ada dalam suatu situasi. Pada bagian lain dinyatakan bahwa metode survai digunakan bukan saja untuk membandingkan kondisikondisi tersebut dengan kriteria yang telah ditetapkan sebelumnya atau untuk menilai keefektifan program, melainkan survai dapat juga digunakan untuk menyelidiki hubungan atau untuk menguji hipotesis.

Desain penelitian dalam penelitian ini dapat digambarkan sebagai berikut :

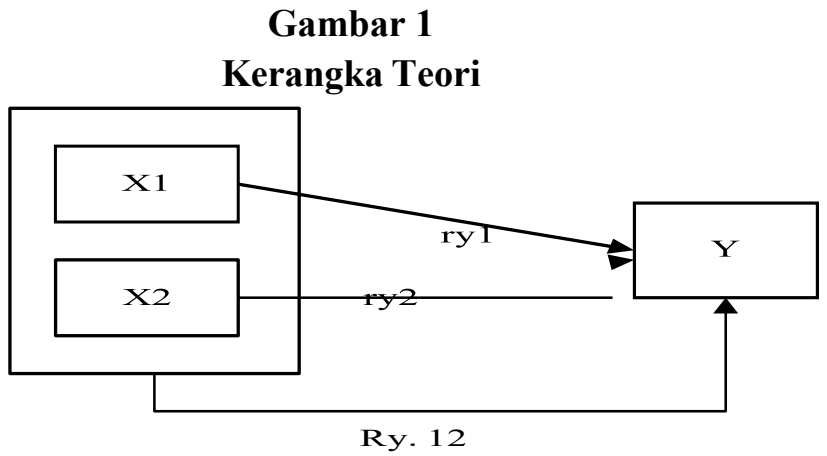

Keterangan:

$\mathrm{X}_{1}$ : Disiplin Kerja

$\mathrm{X}_{2}$ : Komunikasi

$\mathrm{Y} \quad$ : Kinerja pegawai rekam medik 
$r_{\mathrm{y} 1}$ : Koefisien korelasi antara $\mathrm{X}_{1}$ dengan Y

$r_{\mathrm{y} 2}$ : Koefisien korelasi antara $\mathrm{X}_{2}$ dengan $\mathrm{Y}$

$\mathrm{R}_{\mathrm{y} .12}$ : Koefisien korelasi berganda antara $\mathrm{X}_{1}$ dan $\mathrm{X}_{2}$ secara bersama-sama dengan $\mathrm{Y}$

\section{Hasil Penelitian}

Deskripsi data hasil penelitian dimaksudkan untuk memberikan gambaran umum mengenai penyebaran/distribusi data, baik berupa ukuran gejala sentral, ukuran letak maupun distribusi frekuensi. Harga-harga yang akan disajikan setelah diolah dari data mentah dengan menggunakan metode statistik deskriptif, yaitu; harga rata-rata, simpangan baku, modus, median, distribusi frekuensi serta grafik histogram.

Berdasarkan banyaknya variabel dan merujuk kepada masalah penelitian, maka deskripsi data dapat dikelompokkan menjadi tiga bagian yakni; (1) disiplin Kerja, (2) komunikasi interpersonal, dan (3) kinerja pegawai rekam medik. Hasil perhitungan statistik deskriptif masing-masing variabel secara lengkap dapat dilihat pada lampiran 11. Uraian singkat hasil perhitungan statistik deskriptif tersebut akan dikemukakan berikut ini:

\section{Kinerja pegawai}

Hasil penelitian menunjukkan bahwa rentangan skor variabel kinerja pegawai rekam medik berada antara 124 sampai dengan 138 dari skor teoretik 30 hingga 150, skor rata-rata sebesar 131,34, simpangan baku atau standar deviasi sebesar 3,279, median sebesar 131, mode sebesar 130. Sedangkan distribusi frekuensi dapat dilihat pada tabel 4.
Tabel 4

Distribusi Frekuensi Kinerja Pegawai

\begin{tabular}{llll}
\hline No. & Kelas Interval & Frek. Absolut & Frek. Relatif \\
\hline 1. & $124-127$ & 3 & 9,37 \\
2. & $128-130$ & 12 & 43,75 \\
3. & $131-132$ & 4 & 15,63 \\
4. & $133-136$ & 10 & 31,25 \\
5. & $137-138$ & 2 & 9,37 \\
\hline \multicolumn{2}{l}{ Jumlah } & 32 & 100,00 \\
\hline
\end{tabular}

Dari data yang terlihat pada tabel distribusi frekuensi di atas, jika dibandingkan dengan harga rata-rata menunjukkan bahwa skor kinerja pegawai yang berada di bawah harga rata-rata sebanyak 15 responden (46,87\%), sedang yang berada pada kelompok kelas harga rata-rata adalah sebanyak 4 responden $(12,50 \%)$ dan yang berada di atas harga rata-rata sebanyak 12 responden $(43,75 \%)$. Dengan demikian dapat disimpulkan bahwa kinerja pegawai rekam medik Rumah Sakit Dustira Cimahi Jawa Barat termasuk dalam kategori rendah. Selanjutnya histogram variabel ini dapat ditunjukkan pada Grafik 1.

\section{Grafik 1}

Histogram Frekuensi Kinerja Pegawai rekam medik

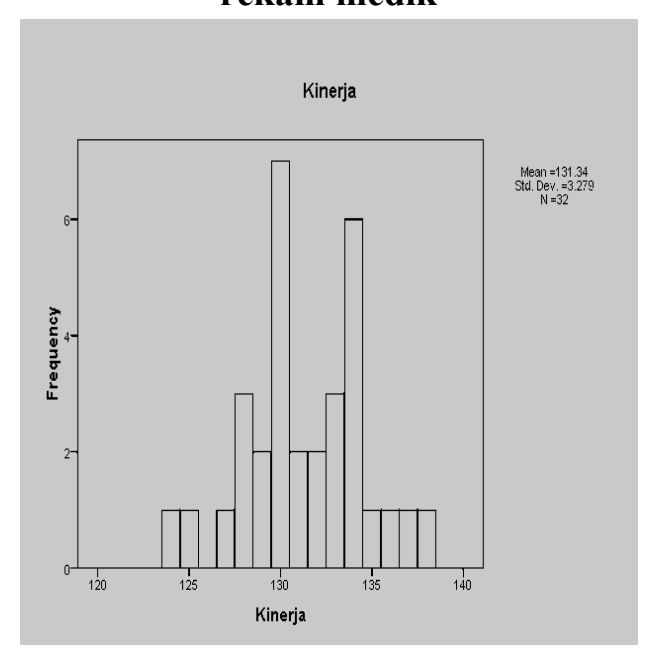


2. Disiplin Pegawai Rekam medik

Skor teoretik yang diharapkan diperoleh pegawai rekam medik dari variabel disiplin kerja adalah terletak pada rentangan skor antara 30 sampai 150. Ternyata hasil penelitian menunjukkan bahwa disiplin kerja hanya berada antara 127 sampai dengan 137, skor rata-rata sebesar 131,62 simpangan baku atau standar deviasi sebesar 2,50, median sebesar 131, modus sebesar 130 . Distribusi frekuensi dapat dilihat pada Tabel 5.

Tabel 5

Distribusi Frekuensi Disiplin Kerja

\begin{tabular}{llll}
\hline No. & Kelas Interval & Frek. Absolut & Frek. Relatif \\
\hline 1. & $124-126$ & 2 & 6,25 \\
2. & $127-130$ & 13 & 40,62 \\
3. & $131-132$ & 4 & 12,50 \\
4. & $133-135$ & 10 & 31,25 \\
5. & $136-138$ & 3 & 9,37 \\
\hline \multicolumn{2}{l}{ Jumlah } & 32 & 100,00 \\
\hline
\end{tabular}

Berdasarkan tabel distribusi frekuensi di atas, jika dibandingkan dengan harga rata-rata menunjukkan bahwa skor disiplin pegawai yang berada di bawah harga rata-rata sebanyak 15 responden $(46,87 \%)$, sedang yang berada pada kelompok kelas harga rata-rata adalah sebanyak 4 responden $(12,50 \%)$ dan yang berada di atas harga rata-rata 13 responden (40,62\%). Dengan demikian dapat disimpulkan bahwa disiplin kerja pegawai rekam medik Rumah Sakit Dustira Cimahi Jawa Barat termasuk dalam kategori rendah. Selanjutnya histogram variabel ini dapat ditunjukkan pada Grafik 2.
Grafik 2

Histogram Frekuensi Disiplin Kerja

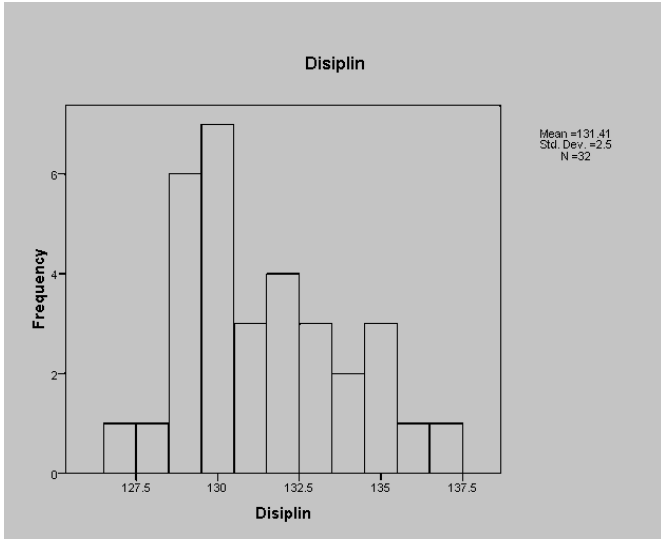

3. Komunikasi Interpersonal

Skor teoretik yang diharapkan diperoleh dari penelitian untuk variabel komunikasi interpersonal adalah berada pada rentangan skor antara 30 sampai 150. Ternyata hasil penelitian menunjukkan bahwa skor komunikasi interpersonal hanya berada antara 127 sampai dengan 138, skor rata-rata sebesar 131,62 simpangan baku atau standar deviasi sebesar 2,50, median sebesar 132 modus sebesar 129. Sedangkan distribusi frekuensi dapat dilihat pada Tabel 6 .

Tabel 6

Distribusi Frekuensi Komunikasi Interpersonal

\begin{tabular}{llll}
\hline No. & Kelas Interval & Frek. Absolut & Frek. Relatif \\
1. & $127-128$ & 4 & 12,50 \\
2. & $129-130$ & 7 & 21,87 \\
3. & $131-132$ & 10 & 31,25 \\
4. & $133-134$ & 7 & 21,87 \\
5. & $135-138$ & 4 & 12,50 \\
\hline \multicolumn{2}{l}{ Jumlah } & 32 & 100,0
\end{tabular}

Dari data yang terlihat pada tabel distribusi frekuensi di atas, jika dibandingkan dengan harga rata-rata menunjukkan bahwa 
skor komunikasi interpersonal yang berada di bawah harga rata-rata sebanyak 11 responden $(34,37 \%)$, sedang yang berada pada kelompok kelas harga rata-rata adalah sebanyak 10 responden $(31,25 \%)$ dan yang berada di atas harga rata-rata 11 responden $(34,37 \%)$. Dengan demikian dapat disimpulkan bahwa komunikasi interpersonal di Rumah Sakit Dustira Cimahi Jawa Barat termasuk dalam kategori sedang. Selanjutnya histogram variable ini dapat ditunjukkan pada Grafik 3.

\section{Grafik 3}

Histogram Frekuensi Komunikasi Interpersonal

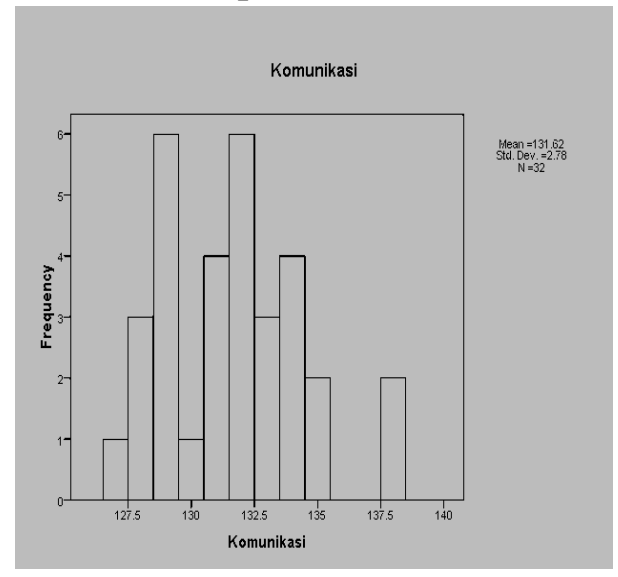

\section{Pembahasan Hasil Penelitian}

Berdasarkan hasil pengujian hipotesis, ternyata ketiga hipotesis alternatif yang diajukan secara signifikan dapat diterima. Uraian masing-masing penerimaan ketiga hipotesis yang dimaksud dapat dijelaskan sebagai berikut:

Pertama, pengujian hipotesis pertama menyimpulkan bahwa terdapat pengaruh positif yang signifikan disiplin kerja terhadap kinerja pegawai rekam medik yang ditunjukkan oleh nilai $t_{\text {hitung }}$ sebesar 3,419 lebih besar dari pada nilai $t_{\text {tabel }}$ pada taraf signifikansi alpha 0,05 yaitu 1,70 atau $3,419>$ $\mathrm{t}_{0,05}=1,70$. Pola hubungan antara kedua variabel ini dinyatakan oleh persamaan regresi $\hat{Y}=40,09+0,69 X_{1}$ Persamaan ini memberikan informasi bahwa setiap perubahan satu unit disiplin kerja akan dapat mengakibatkan terjadinya perubahan kinerja pegawai rekam medik sebesar 0,69 pada konstanta 40,09.

Hasil analisis korelasi sederhana antara disiplin kerja dengan kinerja pegawai rekam medik diperoleh nilai koefisien korelasi $\mathrm{r}_{\mathrm{y} 1}$ sebesar 0,530. Nilai ini memberikan pengertian bahwa keterkaitan antara disiplin kerja dengan kinerja pegawai rekam medik cukup dan positif, artinya makin tinggi disiplin kerja seorang pegawai rekam medik makin tinggi pula kinerja pegawai rekam medik tersebut. Demikian pula sebaliknya, makin rendah disiplin kerja seorang pegawai rekam medik, makin rendah pula kinerja pegawai rekam medik tersebut.

Besarnya sumbangan atau kontribusi variabel disiplin kerja terhadap kinerja pegawai rekam medik dapat diketahui dengan jalan mengkuadratkan peroleh nilai koefisien korelasi sederhananya. Hasil pengkuadratan nilai koefisien korelasi sederhananya adalah sebesar 0,28. Secara statistik nilai ini memberikan pengertian bahwa kurang lebih 28 persen variasi perubahan kinerja seorang pegawai rekam medik ditentukan/dijelaskan oleh disiplin kerja pegawai rekam medik tersebut dengan pola hubungan fungsionalnya seperti ditunjukkan oleh persamaan regresi tersebut di atas. Artinya, jika seluruh pegawai rekam medik di Rumah Sakit Dustira Cimahi dites disiplin kerja dan kinerjanya, maka lebih kurang 28 persen variasi pasangan skor kedua variabel tersebut akan berdistribusi dan mengikuti pola hubungan antara variabel disiplin kerja dengan kinerja pegawai rekam medik sesuai persamaan garis regresi $\hat{Y}=$ $40,09+0,69 \mathrm{X}_{1}$. 
Kedua, pengujian hipotesis kedua menyimpulkan bahwa terdapat pengaruh positif yang sangat signifikan antara Komunikasi interpersonal dengan kinerja pegawai rekam medik yang ditunjukkan oleh nilai thitung sebesar 7,314 jauh lebih besar dari pada nilai $t_{\text {tabel }}$ pada taraf signifikansi alpha 0,05 yaitu 1,70 atau $\mathrm{t}=7,314>\mathrm{t}_{0,05}=1,70$. Pola hubungan antara kedua variabel ini dinyatakan oleh persamaan regresi $\hat{Y}=7,069$ $+0,94 X_{1}$.

Persamaan ini memberikan informasi bahwa setiap perubahan satu unit skor Komunikasi interpersonal akan mengakibatkan terjadinya perubahan skor kinerja pegawai rekam medik sebesar 0,94 pada konstanta 7,069 .

Hasil analisis korelasi sederhana antara komunikasi interpersonal dengan kinerja pegawai rekam medik diperoleh nilai koefisien korelasi $\mathrm{r}_{\mathrm{y} 2}$ sebesar 0,800 . Nilai ini memberikan pengertian bahwa keterkaitan antara Komunikasi interpersonal dengan kinerja pegawai rekam medik cukup dan positif, artinya makin baik komunikasi interpersonal pada seorang pegawai rekam medik akan makin tinggi pula kinerja pegawai rekam medik tersebut. Demikian pula sebaliknya, makin kurang baik komunikasi interpersonal pada seorang pegawai rekam medik, makin rendah pula prestasi kerjanya.

Besarnya sumbangan atau kontribusi variabel komunikasi interpersonal terhadap kinerja pegawai rekam medik dapat diketahui dengan jalan mengkuadratkan nilai koefisien korelasi sederhananya. Hasil pengkuadratan nilai koefisien korelasi sederhananya adalah sebesar 0,64. Secara statistik nilai ini memberikan pengertian bahwa kurang lebih 64 persen variansi perubahan kinerja seorang pegawai rekam medik ditentukan/dijelaskan oleh komunikasi interpersonalnya dengan pola hubungan fungsionalnya seperti ditunjukkan oleh persamaan regresi tersebut di atas. Artinya jika seluruh pegawai rekam medik di Rumah Sakit Dustira Cimahi diukur komunikasi interpersonal dan kinerjanya, maka lebih kurang 64 persen variasi pasangan skor kedua variabel tersebut akan berdistribusi dan mengikuti pola hubungan antara variabel komunikasi interpersonal dengan kinerja pegawai rekam medik melalui persamaan garis regresi $\hat{Y}=7,069+0,94 X_{2}$.

Ketiga, pengujian hipotesis menyimpulkan terdapat pengaruh yang positif disiplin kerja dan komunikasi interpersonal secara bersama-sama terhadap kinerja pegawai rekam medik yang ditunjukkan oleh nilai $F_{\text {hitung }}$ sebesar 29,28. Nilai ini jauh lebih besar dari pada nilai $F_{\text {hitung }}$ pada taraf signifikansi alpha 0,05 yaitu 2,91 , atau $\mathrm{F}=$ $29,28>F_{0,05}=2,91$. Pola hubungan antara ketiga variabel yang dinyatakan oleh persamaan regresi ganda $\hat{Y}=11,66+0,25 X_{1}$ $+0,84 X_{2}$. Persamaan ini memberikan informasi bahwa setiap perubahan satu unit skor disiplin kerja dan komunikasi interpersonal akan mengakibatkan terjadinya perubahan kinerja pegawai rekam medik sebesar 0,25 atau 0,84 .

Hasil analisis korelasi ganda antara disiplin kerja dan komunikasi interpersonal diperoleh nilai koefisien korelasi ganda sebesar $\mathrm{R}_{\mathrm{y} 12}$ sebesar 0,818. Nilai ini menunjukkan bahwa keterkaitan antara disiplin kerja dan komunikasi interpersonal secara bersama-sama dengan kinerja pegawai rekam medik tinggi dan positif. Dengan demikian berarti makin tinggi disiplin kerja seorang pegawai rekam medik dan makin baik komunikasi interpersonal, makin tinggi pula kinerja pegawai rekam medik tersebut. Sebaliknya makin rendah disiplin kerja seorang pegawai rekam medik dan makin 
kurang baik komunikasi interpersonalnya, makin rendah pula kinerja pegawai rekam medik tersebut.

Besarnya sumbangan atau kontribusi variabel disiplin kerja dan komunikasi interpersonal secara bersama-sama dapat diketahui melalui nilai koefisien determinasi sebesar 0,67. Hasil analisis tersebut menunjukkan bahwa lebih kurang 67 persen variasi perubahan kinerja pegawai rekam medik ditentukan/dijelaskan oleh disiplin kerja dan komunikasi interpersonal secara bersama-sama dengan pola hubungan fungsionalnya seperti ditunjukkan oleh persamaan regresi tersebut di atas. Artinya jika seluruh pegawai rekam medik di Rumah Sakit Dustira Cimahi diteliti disiplin kerja dan komunikasi interpersonal secara bersamasama dengan melihat kinerja pegawai rekam mediknya, maka lebih kurang 67 persen variasi pasangan skor ketiga variabel akan mengikuti pola persamaan regresi $\hat{Y}=11,66$ $+0,25 \mathrm{X}_{1}+0,84 \mathrm{X}_{2}$.

\section{Kesimpulan}

Hasil pengujian hipotesis menunjukkan bahwa ketiga hipotesis alternatif $\left(\mathrm{H}_{\mathrm{a}}\right)$ yang diajukan dalam penelitian ini diterima, dan menolak hipotesis nol $\left(\mathrm{H}_{0}\right)$. Beberapa kesimpulan penelitian dapat dirumuskan sebagai berikut:

Pertama, terdapat pengaruh positif antara disiplin kerja dengan kinerja pegawai rekam medik Rumah Sakit Dustira Cimahi. Ini berarti bahwa makin tinggi disiplin kerja seorang pegawai rekam medik makin tinggi pula kinerja pegawai rekam medik tersebut. Demikian pula sebaliknya, makin rendah disiplin kerja seorang pegawai rekam medik, makin rendah pula kinerja pegawai rekam medik tersebut. Oleh karena itu disiplin kerja merupakan variabel yang penting untuk diperhatikan dalam memprediksi kinerja pegawai rekam medik.

Berdasarkan hasil pengujian koefisien korelasi dengan menggunakan rumus analisis uji $\mathrm{t}$ diperoleh nilai $\mathrm{t}_{\text {hitung }}=$ 3,419 sedangkan harga $t_{\text {tabel }}$ sebesar 1,70. Dengan demikian dapat dikatakan bahwa terdapat pengaruh yang positif terhadap disiplin kerja dengan kinerja pegawai rekam medik, karena kriteria perhitungan adalah $\mathrm{t}_{\text {hitung }}>\mathrm{t}_{\text {tabel }}(3,419>1,70)$.

Meskipun secara statistik berhasil diuji terdapat hubungan yang positif antara kedua variabel, peneliti menyadari bahwa faktor disiplin kerja bukanlah satu-satunya faktor yang menentukan tinggi rendahnya kinerja pegawai rekam medik. Masih ada faktor lain yang mungkin berperan terhadap kinerja seperti komunikasi interpersonal, aktualisasi diri, disiplin kerja, promosi jabatan, pengetahuan pegawai rekam medik, keterampilan kerja, dan faktor lainnya yang tidak diteliti dalam penelitian ini.

Kedua, terdapat pengaruh positif antara komunikasi interpersonal terhadap kinerja pegawai rekam medik Rumah Sakit Dustira Cimahi. Ini berarti bahwa makin baik komunikasi interpersonal pada seorang pegawai rekam medik, makin tinggi kinerja pegawai rekam medik tersebut. Demikian pula sebaliknya, makin kurang baik komunikasi interpersonal pada seorang pegawai rekam medik, makin rendah pula kinerja pegawai rekam medik tersebut. Oleh karena itu komunikasi interpersonal merupakan variabel yang penting untuk diperhatikan di dalam memprediksi kinerja pegawai rekam medik.

Berdasarkan hasil pengujian koefisien korelasi dengan menggunakan rumus analisis uji $\mathrm{t}$ diperoleh nilai $\mathrm{t}_{\text {hitung }}=$ 7,314 sedangkan harga $t_{\text {tabel }}$ sebesar 1,70 . 
Dengan demikian dapat dikatakan bahwa terdapat hubungan yang positif antara komunikasi interpersonal dengan kinerja pegawai rekam medik, karena kriteria perhitungan adalah $t_{\text {hitung }}>\mathrm{t}_{\text {tabel }}(7,314>$ $1,70)$.

Meskipun secara statistik berhasil diuji terdapat hubungan yang positif antara kedua variabel, peneliti menyadari bahwa faktor komunikasi interpersonal bukanlah satu-satunya faktor yang menentukan tinggi rendahnya kinerja pegawai rekam medik. Masih ada faktor lain yang mungkin berperan terhadap kinerja seperti disiplin kerja, aktualisasi diri, disiplin kerja, promosi jabatan, pengetahuan pegawai rekam medik, keterampilan kerja, dan faktor lainnya yang tidak diteliti dalam penelitian ini.

Ketiga, terdapat pengaruh positif antara disiplin kerja dan komunikasi interpersonal secara bersama-sama dengan kinerja pegawai rekam medik Rumah Sakit Dustira Cimahi. Dengan demikian berarti bahwa makin tinggi disiplin kerja seorang pegawai rekam medik dan makin baik komunikasi interpersonal, makin tinggi pula kinerja pegawai rekam medik tersebut. Sebaliknya makin rendah disiplin kerja seorang pegawai rekam medik dan makin kurang baik komunikasi interpersonal, makin rendah pula kinerja pegawai rekam medik tersebut. Kondisi ini menunjukkan bahwa disiplin kerja dan komunikasi interpersonal, merupakan dua variabel yang penting untuk diperhatikan dalam menjelaskan peningkatan kinerja seorang pegawai rekam medik.

Hasil analisis uji "F" diperoleh besaran sebesar 29,28. Besaran ini dikonsultasikan dengan besaran $\mathrm{F}_{\text {tabel }}(0.05)$ diperoleh besaran sebesar 2,91, yang menunjukkan bahwa koefisien korelasi antara disiplin kerja dan komunikasi interpersonal secara bersama-sama dengan kinerja pegawai rekam medik sangat signifikan.

\section{BIBILIOGRAFI}

Afriandi, Suhendra. (2017). Meningkatkan Produktivitas Kerja Di Perusahaan Jasa Survey. Syntax Literate; Jurnal Ilmiah Indonesia, 2(2), 133-143.

Attamimi, Yasir. (2020). Pengaruh Disiplin Kerja, Kepuasan Kerja Dan Motivasi Kerja Terhadap Kinerja Karyawan Perusahaan Daerah Air Minum Delta Tirta Sidoarjo. Universitas, 2(7).

Djalali, Fatmawati. (2016). Analisis Pengaruh Kompensasi Dan Lingkungan Kerja Terhadap Kepuasan Kerja Dan Kinerja Pegawai. Jurnal Riset Bisnis Dan Manajemen, 3(4).

Hermawati, Wawat. (2017). Pengaruh Aplikasi Manajemen Logistik Dan Disiplin Pegawai Terhadap Kinerja Pegawai Pada Sekretariat Daerah Kabupaten Kuningan. Syntax Literate; Jurnal Ilmiah Indonesia, 2(7), 130-153.

Irwansyah, Edy, Adhinugraha, Sena, \& Wijaya, Tri Datara. (2011). Pengembangan Sistem Informasi Geografis (SIG) pada Platform Google untuk Penanggulangan Kebakaran di Jakarta Selatan. Seminar Nasional Aplikasi Teknologi Informasi (SNATI).

M. Yani, Mulya. (2014). Peran Manajemen Kinerja Dalam Meningkatkan Kinerja Pegawai Kantor Kementerian Agama Pekanbaru. Retrieved from http://repository.uinsuska.ac.id/419/1/FM.pdf

Nurcahyo, Anton. (2011). Analisis VariabelVariabel Yang Mempengaruhi Kinerja Karyawan Pada PT. Quadra Mitra Perkasa Balikpapan. Jurnal Eksis, 7(2), 
1972-1982.

Pusparini, Adriana. (2008). Faktor Biologi di Tempat Kerja. Universitas Diponegoro. Semarang.

Putra, Udin, Hasanuddin, Bakri, \& Wirastuti, Wiri. (2018). Pengaruh Motivasi Kerja Dan Kompensasi Terhadap Kinerja Karyawan Pada Pt. Balindo Manunggal Bersama Kota Palu. Jurnal Ilmu Manajemen Universitas Tadulako, 4(1), $1-10$.

Rochmanadji. (2009). dalam "Being a Great and Sustainable Hospital." Jakarta: Gramedia Pustaka Utama.

Siswadi, Yudi. (2014). Analisis faktor internal, faktor eksternal dan pembelajaran kewirausahaan yang mempengaruhi minat mahasiswa dalam berwirausaha. Jurnal Ilmiah Manajemen Dan Bisnis, 13(1).

Sutanto, Eddy Madiono, \& Suwondo, Diah Indriani. (2015). Hubungan lingkungan kerja, disiplin kerja, dan kinerja karyawan. Jurnal Manajemen Dan Kewirausahaan, 17(2), 135-144.

Taurisa, Chaterina Maulina, Djastuti, Indi, \& Ratnawati, Intan. (2012). Analisis pengaruh budaya organisasi dan kepuasan kerja terhadap komitmen organisasional dalam meningkatkan kinerja karyawan (Studi pada PT. Sido Muncul Kaligawe Semarang). Diponegoro University.
Utomo, Sudibyo Budi, \& Nuraeni, Siti. (2019). Pengaruh Kemampuan dan Kepuasan Kerja Terhadap Produktivitas Karyawan Pada Pabrik Tahu di Desa Citeureup Kecamatan Kawali Kabupaten Ciamis. Syntax Literate; Jurnal Ilmiah Indonesia, 4(12), 180186.

\section{Copyright holder:}

Sari Hijayanti (2020)

First publication right:

Jurnal Health Sains

This article is licensed under:

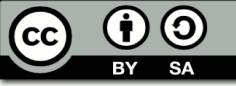

